\title{
ERB-DUCHENNE PALSY (CASE REPORT)
}

\author{
Senatorova A. V., Khodun I. I.
}

\section{Kharkiv National Medical University, Ukraine}

\begin{abstract}
The frequency of damage to the brachial plexus is $0.5-2$ per 1000 live births. Most of them (about $90 \%$ cases) are Erb-Duchesnne palsy. Birth trauma of the brachial plexus occurs mainly in in full-term newborns. Correct diagnosis of Erb-Duchesnne palsy allows to avoid long-term complications as late treatment leads to disability. The article presents a clinical observation of Erb-Duchesnne palsy in a newborn patient, who was diagnosed on the first day of life. Conservative therapy was an effective strategy of baby's recovery.
\end{abstract}

Key words: Erb-Duchenne palsy, birth injury, brachial plexus, newborn.

The neonatal period of a child's life is the most important stage of human ontogeny, during which the formation and rapid development of all functional systems of the organism occur. The period of newborn is highlighted due to the special dynamism of the process of postnatal adaptation, and the greatest risk of disruption of this adaptation, much higher rates of morbidity and mortality. In our country in recent decades, research in neonatology has become importante due to the fact that at the present time the critical features of the neonatal ontogenesis are combined with extremely unfavorable social, biological and environmental factors, as well as with a severe demographic situation - the decline in fertility, short life expectancy and as a result a decrease in the population of Ukraine.

Erb-Duchenne palsy. ICD-10 / P00-P96 CLASS XVI Individual conditions originating in the perinatal period / P10-P15 Birth injury / P14 Birth injury of the peripheral nervous system.

P14.0 Erb-Duchenne palsy with birth injury

P14.1 Kliumpke palsy with birth injury

P14.2 Diaphragmatic nerve palsy with birth injury

P14.3 Other birth injuries of the brachial plexus

Corresponding Author:

Anastasiya Senatorova, MD, PhD,

Professor asssistant of Department of Pediatrics 1

and Neonatology of Kharkiv National

Medical Univeristy, Ukraine.

E-mail: anastasya.senatorova@gmail.com
P14.8 Birth injuries of other parts of the peripheral nervous system

P14.9 Birth injury of peripheral nerves, "unspecified"

The proximal (upper) type, or Erb-Duchenne palsy (P14.0) (damage to rootlets from C5-C6 segments) is the most common type of palsy [1]. The following nerves and muscles are usually involved in the pathological process: n.axillaris (m.deltoideus), n.musculocutaneus (m.biceps et brachialis), n.radialis (m.brachioradialis et $\mathrm{m}$.supinator brevis), n.suprascapularis (m. infraspinalis) [2]. This leads to atrophy of the shoulder muscles oand forearm and to impossibility of lifting the shoulder to the horizontal line, flexing the forearm, supination of the forearm and hand. The affected limb hangs drowsily along the torso and is rotated somewhat inward, as a result of which there is a Novik's symptom ("puppet hands"). The head is inclined to the lowered paretic shoulder, the hand is in the position of palmar flexion. Reflexes from the biceps are not caused. The paretic limb does not participate in the Moro reflex, grasping reflex is partially preserved. Muscle strength is reduced. There are no tendon reflexes with $\mathrm{m}$. biceps, $\mathrm{m}$. brachioradialis and $\mathrm{m}$. triceps [3]. With a severe form of the paresis, a subluxation or dislocation of the head of the humerus can be observed due to a sharp decrease in muscle tone that fixes the shoulder joint. There is a symptom of Fink's "click". Sensitivity in the deltoid region is impaired. In $5 \%$ of cases, $\mathrm{C} 3-\mathrm{C} 4$ rootlets are involved in the pathological process, which is accompanied by damage of the diaphragmatic nerve. In such cases, in addition to limb palsy, respiratory 
disorders (rapid breathing, cyanosis, hiccough, dyspnea) are observed, especially with anxiety and screaming [4].

Along with Erb-Duchenne palsy, the distal lower Dejerine-Clumpke palsy, caused by the injury of the lower parts of the brachial plexus (C8-Th1) and total palsy of Kerer (C5-Th1 damage level) [5]. Duchesne-Erb palsy occurs more frequently in comparison with other diseases; in obstetrical practice its frequency is 1-2 cases per thousand newborns. Despite the developed methods of diagnosis and treatment, this pathology continues to be an urgent problem for a number of medical disciplines (neurology, orthopedics and traumatology, pediatrics, neonatology, obstetrics and gynecology).

The condition is mainly observed in full-term newborns. The frequency of damages of the brachial plexus is $0.5-2$ per 1000 live births; among them, $90 \%$ of cases are Erb-Duchenne palsy [6].

The leading mechanism of the disease is stretching of the brachial plexus and neural roots, which form it and are fixed in the cervical spinal cord, due to excessive lateral (side) traction [7]. Thus, tractions and turn over the shoulder during the eruption of the head in case of breech presentation is a main cause of Erb-Duchenne palsy.

The upper roots of the plexus are most vulnerable, and as a result of excessive traction they are more often damaged. In severe cases of damage, detachment of the roots from the spinal cord, which can be accompanied by damage to the spinal cord itself, is present.

With less severe injury, hemorrhage and edema are observed in combination with rupture of the rootlets covers [8].

Important factors are maternal diabetes, excessive weight gain during pregnancy, which lead to embryonic macrosomia, which increases the risk of injury during childbirth.

It is not necessary to exclude the role of noncoordinated childbirth and rapid childbirth in the development of this pathology. It should be clarified that childbirth by caesarean section reduces, but does not completely eliminate the risk [9].

According to some sources, congenital varicella syndrome, as well as osteomyelitis of the head of the humerus or cervical vertebrae (due to plexus ischemia) can lead to complete palsy of the brachial plexus [10].

\section{CLINICAL CASE}

A child from the first pregnancy against a background of chronic tonsillopharyngitis in remission, anemia of mild degree from week 32. Baby from the first delivery at the gestational age of 39 weeks. The amniotic fluid was clear. Apgar score: at 1 minute -6 points, at $5 \mathrm{~min}-8$ points.

At birth, the body weight was $3795 \mathrm{~g}$, length $50 \mathrm{~cm}$, head circumference $35 \mathrm{~cm}$, chest circumference $37 \mathrm{~cm}$.

Resuscitation measures were carried out in the hospital: sanation of the upper respiratory tract, artificial ventilation of the lungs with the Ambu bag. Cardiovascular system of the umbilical cord blood: $\mathrm{pH}-7,149, \mathrm{PCO} 2-50 \mathrm{mmHg}$.

At the initial examination, the limitation of mobility of the left upper limb was revealed (Fig. 1).

There was no signs of bone injury on X-ray examination.

Immobilization of the left arm by the outboard tire was made.

For further treatment, he was transferred to specialized department for thick neonates.

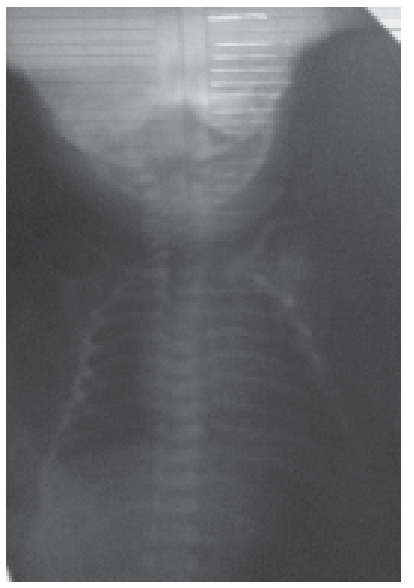

Fig. 2. X-ray, made just after the birth (no signs of injury)

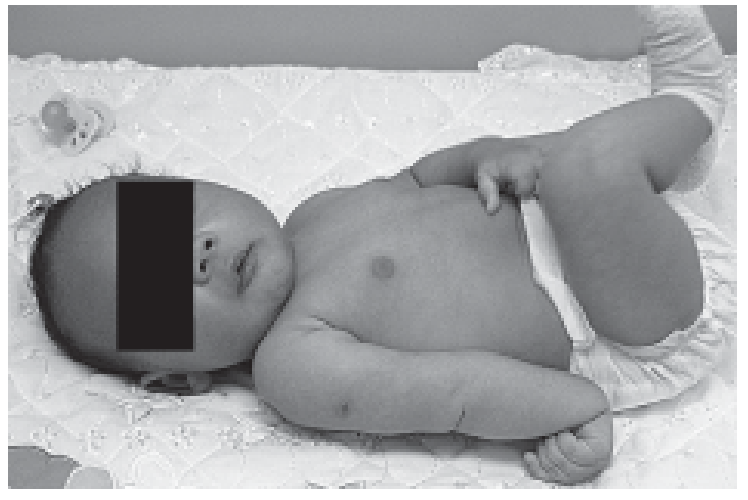

Fig. 1. Position of the right arm of newborn baby 
Laboratory investigations showed the following:

Complete blood count:

\begin{tabular}{|l|l|}
\hline Index & result \\
\hline $\mathrm{Hb}$ & $144 \mathrm{~g} / 1$ \\
\hline Erythrocytes & $4,08 \times 10^{12} / 1$ \\
\hline $\mathrm{Ht}$ & $41 \%$ \\
\hline Platelets & $122 \mathrm{~g} / 1$ \\
\hline BCI & 1,0 \\
\hline Leukocytes & $6,6 \times 10^{9} / 1$ \\
\hline Myelocytes & $1 \%$ \\
\hline Metamyelocytes & $1 \%$ \\
\hline Stabbed & $5 \%$ \\
\hline Segmented & $27 \%$ \\
\hline Eozinofiles & $4 \%$ \\
\hline Lymphocytes & $55 \%$ \\
\hline Monocytes & $7 \%$ \\
\hline
\end{tabular}

Blood glucose-3,6 mmol / 1

Clinical urinalysis:

\begin{tabular}{|l|l|}
\hline Index & result \\
\hline Color & yellow \\
\hline Transparency & clear \\
\hline Ph & acidic \\
\hline Glucose & - \\
\hline Protein & - \\
\hline Leukocytes & - \\
\hline
\end{tabular}

Coprogram

\begin{tabular}{|l|l|}
\hline Index & result \\
\hline Color & Yellow \\
\hline Neutral fat & Some \\
\hline Leukocytes & - \\
\hline Erythrocytes & - \\
\hline
\end{tabular}

Cranial ultrasound investigation: Echoes of edema of the brain, mainly periventricular zones.

Doppler-echocardioscopy: Patent foramen ovale, patent ductus arteriosus.

Orthopedic specialist diagnosed left-sided upper monoparesis, pronation-flexion system in the left elbow joint.
Neurologist confirmed the birth injury of the peripheral nervous system, left-sided ErbDuchenne palsy.

Management. Immobilization of the left arm with an abducting splint, placement in the middle physiological position.

According to modern sources, the initial treatment is conservative. Physiotherapy and exercises with passive movements are indicated to prevent contractures (they can be started at the age of 7-10 days, after the extinction of postinjury neuritis). It is necessary to avoid the position of the "Statue of Liberty", as this leads to the development of contractures in the immobile shoulder. It can be helpful to overlay the longes on the wrist and fingers [6].

If the child does not noticeably improve the functionality of the affected arm in the first six months, surgical correction is usually recommended.

The prognosis of full recovery depends on the severity of the damages. If the roots of the nerves are not damaged and not broken, the prognosis is almost good ( $>90 \%$ ). If a significant improvement is observed during the first 2 weeks after birth, this indicates a complete or almost complete restoration of the plexus function. In most children, it is fully restored until the $3 \mathrm{rd}$ month of life. With a slow recovery, electromyography and investigation of the conductivity of the nerves make it possible to distinguish from avulsion (separation of the roots of the nerves from the spinal cord) from their stretching [6].

\section{CONCLUSIONS}

Erb-Duchenne palsy is a the condition that can be controlled. Its main symptoms in the form of restriction of movements in the shoulder and elbow joints can be minimized if medical aid is sought timely and drift.

Prophylaxis of the genital palsy of Erb is the adequate management of pregnancy and childbirth, the correct choice of the method of childbirth, which makes it possible to avoid the need for obstetric obstetrical manipulations.

\section{Conflict of interests}

There is no conflict of interests. 


\section{REFERENCES}

1. McKee Garrett TM. Neonatal birth injuries, 2013.

2. Yang LJ. Neonatal brachial plexus palsy: management and prognostic factors. Semin Perinatol. 2014;38(4).

3. A.A. Baranov. (2015) Klinicheskie rekomendatsii po okazaniyu meditsinskoy pomoschi detyam s posledstviyami perinatalnogo porazheniya tsentralnoy nervnoy sistemyi s sindromom myishechnogo gipertonusa. [Clinical recommendations for the provision of medical care for children with consequences of perinatal involvement of the central nervous system with muscle hypertension syndrome]. pp. 9.

4. Evtushenko S.K., Morozova T.M. (2011) Rodovyie travmyi nervnoy sistemyi. [Birth injuries of the nervous system] Mezhdunarodnyiy nevrologicheskiy zhurnal. № 3(41). pp. 4-11.

5. V. V. Vlasyuk, D. O. Ivanov (2016) Klinicheskie rekomendatsii po diagnostike i lecheniyu rodovoy travmyi. [Clinical recommendations for the diagnosis and treatment of birth trauma.] pp. 19.

6. Warke C, Malik S, Chokhandre M, Saboo A. Birth injuries - A review of incidence, perinatal risk factors and outcome. Bombay Hosp Med J 2012;54:202-8.

7. Suneet P. Chauhan, Kate W-C. Chang, Nana-Ama Esi Ankumah \& Lynda J-S. Yang Neonatal brachial plexus palsy: obstetric factors associated with litigation, 2016.

8. Neonatologiya [Neonatology]. navchalniy posibnik / Za red. T.K. Znamenskoyi. - Kiyiv., 2012. pp. 371-372.

9. Ouzounian JG. Risk factors for neonatal brachial plexus palsy. Semin Perinatol 2014; 38:219. 10. Alfonso DT. Causes of neonatal brachial plexus palsy. Bull NYU Hosp Jt Dis 2011; 69:11.

Received: 22-Apr. - 2018

Accepted: 20-Jun- 2018 